\title{
Elevated insulin-like growth factor 1 receptor signaling induces antiestrogen resistance through the MAPK/ERK and PI3K/Akt signaling routes
}

Yinghui Zhang ${ }^{\dagger}$, Marja Moerkens ${ }^{\dagger}$, Sreenivasa Ramaiahgari, Hans de Bont, Leo Price, John Meerman* and Bob van de Water

\begin{abstract}
Introduction: Insulin-like growth factor 1 (IGF-1) receptor (IGF-1R) is phosphorylated in all breast cancer subtypes. Past findings have shown that IGF-1R mediates antiestrogen resistance through cross-talk with estrogen receptor (ER) signaling and via its action upstream of the epidermal growth factor receptor and human epidermal growth factor receptor 2. Yet, the direct role of IGF-1R signaling itself in antiestrogen resistance remains obscure. In the present study, we sought to elucidate whether antiestrogen resistance is induced directly by IGF-1R signaling in response to its ligand IGF-1 stimulation.
\end{abstract}

Methods: A breast cancer cell line ectopically expressing human wild-type IGF-1R, MCF7/IGF-1R, was established by retroviral transduction and colony selection. Cellular antiestrogen sensitivity was evaluated under estrogendepleted two-dimensional (2D) and 3D culture conditions. Functional activities of the key IGF-1R signaling components in antiestrogen resistance were assessed by specific kinase inhibitor compounds and small interfering RNA.

Results: Ectopic expression of IGF-1R in ER-positive MCF7 human breast cancer cells enhanced IGF-1R tyrosine kinase signaling in response to IGF-1 ligand stimulation. The elevated IGF-1R signaling rendered MCF7/IGF-1R cells highly resistant to the antiestrogens tamoxifen and fulvestrant. This antiestrogen-resistant phenotype involved mitogen-activated protein kinase/extracellular signal-regulated kinase (MAPKJERK) and phosphatidylinositol 3-kinase/protein kinase B pathways downstream of the IGF-1R signaling hub and was independent of ER signaling. Intriguingly, a MAPK/ERK-dependent agonistic behavior of tamoxifen at low doses was triggered in the presence of IGF-1, showing a mild promitogenic effect and increasing ER transcriptional activity.

Conclusions: Our data provide evidence that the IGF-1/IGF-1R signaling axis may play a causal role in antiestrogen resistance of breast cancer cells, despite continuous suppression of ER transcriptional function by antiestrogens.

\section{Introduction}

Acquisition of antiestrogen resistance is a common impediment in endocrine therapy for estrogen receptor (ER)-positive breast cancer. It is therefore imperative to understand the underlying mechanisms of resistance to identify novel therapeutic targets for treatment of resistant breast cancers.

\footnotetext{
*Correspondence: meerman@lacdr.leidenuniv.nl; b.water@lacdr.leidenuniv.nl + Contributed equally

Division of Toxicology, Leiden/Amsterdam Center for Drug Research, Leiden University, Einsteinweg 55, NL-2333 CC, Leiden, The Netherlands
}

The molecular mechanisms of antiestrogen resistance are intricate. The canonical ER pathway responds to estrogen to initiate a series of cell growth events via ER cofactors, cell cycle regulators, cell survival and apoptosis mediators [1-4]. Compelling evidence from clinical and experimental settings links antiestrogen resistance to elevated signaling of receptor tyrosine kinases (RTKs) such as the members of the epidermal growth factor receptor (EGFR) family, EGFR and human epidermal growth factor receptor 2 (HER2) [1-4]. Altered expression and activation of EGFR/HER2 and their key downstream signaling components, mitogen-activated protein
C Biomed Central

(c) 2011 Zhang et al.; licensee BioMed Central Ltd. This is an open access article distributed under the terms of the Creative Commons Attribution License (http://creativecommons.org/licenses/by/2.0), which permits unrestricted use, distribution, and reproduction in any medium, provided the original work is properly cited. 
kinase/extracellular signal-regulated kinase (MAPK/ ERK) and phosphatidylinositol 3-kinase/protein kinase B (PI3K/Akt), can elicit antiestrogen resistance, either through phosphorylation of ER, such as at Ser167 by EGFR/Akt and at Ser118 by HER2/ERK to increase ER DNA binding and ER coactivator interaction, or via other independent pathways, such as upregulated antiapoptotic machinery of B-cell lymphoma 2 (Bcl-2) and Bcell lymphoma extra large (Bcl-xL) [1,4-7]. Furthermore, high EGFR/HER2 RTK signaling not only may promote de novo and acquired antiestrogen resistance but also may signal in an ER-independent manner, thereby promoting cell proliferation in its own right $[1,4-7]$. Signaling networks assembled by RTKs are therefore critical contributors to the development of breast cancer resistance to antiestrogens.

In addition to EGFR/HER2, there is increasing evidence for the involvement of the insulin-like growth factor 1 (IGF-1) receptor (IGF-1R) in antiestrogen resistance. IGF-1R, as part of the large class of RTKs, is now considered a potential cellular oncogene that plays a key role in various cellular processes, such as proliferation, survival, transformation, differentiation as well as cell-cell and cell-substrate interactions [8,9]. In breast neoplastic cell lines, expression of IGF-1R is a fundamental prerequisite for a malignant phenotype, potentially facilitating cell survival and metastasis [8,10-12]. Clinically, IGF-1R is commonly overexpressed in primary breast tumors [13,14] and phosphorylated in all breast cancer subtypes, correlating with poor survival [15]. In ER-positive breast cancer cells, IGF-1R and ER $\alpha$ are often coexpressed and respond to the synergistic action of estrogen and IGF-1 signaling, leading to crosstalk between the ER and IGF-1R pathways [16,17]. In tamoxifen-resistant breast cancer cells, IGF-1R is upregulated [18-20] and acts upstream of estrogen-activated EGFR [21,22]. Moreover, IGF-1R confers resistance by forming a heterodimer with HER2, allowing HER2 signaling to resume in the presence of trastuzumab [23]. While the accumulating data just described show that IGF-1R operates through signaling cross-talk with estrogen-ER signaling and EGFR/HER2 regulatory pathways in antiestrogen-resistant breast cancer cells, the ERindependent role of IGF-1R signaling in antiestrogen resistance is poorly understood $[1,4]$.

To elucidate the direct role of IGF-1R signaling in breast cancer antiestrogen resistance, we established an ER-positive human breast cancer cell line ectopically expressing human wild-type IGF-1R, MCF7/IGF-1R, with elevated IGF-1R tyrosine kinase activity. In the present study, we demonstrate that while MCF7/IGF-1R cells remain antiestrogen-responsive, IGF-1 ligand stimulation induces rapid and sustained IGF-1R/MAPK/PI3K signaling and directly causes an ER $\alpha$-independent resistance to the antiestrogens tamoxifen and fulvestrant (FUL) in two-dimensional (2D) as well as 3D culture. In addition, tamoxifen at low doses functions as an agonist in IGF-1stimulated MCF7/IGF-1R cells, further increasing IGF-1dependent proliferation. Our results indicate that IGF-1R signaling can be a single determinant for antiestrogen efficacy and hence suggest that IGF-1R and the key components involved in the IGF-1R signaling network are potential targets in combined antiestrogen therapy.

\section{Materials and methods Antibodies and reagents}

Antibodies to rabbit anti-phospho-IGF-1R $\beta$ (Tyr1131), anti-phospho-IGF-1R (Tyr1135/Tyr1136), anti-ERK1/2, anti-phospho-ERK1/2 (Thr202/Tyr204), anti-Akt and anti-phospho-Akt (Ser473) (Cell Signaling Technology Danvers, MA, USA), mouse anti-IGF-1R $\beta$ and rabbit antiER $\alpha$ (Santa Cruz Biotechnology, Santa Cruz, CA, USA), and mouse antitubulin (Sigma-Aldrich, St. Louis, MO, USA) were commercially purchased. Conjugated secondary antibodies included Alexa Fluor 488 antimouse (Jackson ImmunoResearch, West Grove, PA, USA), antimouse horseradish peroxidase (HRP) and antirabbit HRP (Jackson ImmunoResearch, West Grove, PA, USA), and antirabbit alkaline phosphatase (AP) (Tropix WesternSuperStar ${ }^{\mathrm{TM}}$ Immunodetection System; Applied Biosystems, Foster, CA, USA). Human IGF-1 (Sigma-Aldrich) was prepared in sterile $\mathrm{H}_{2} \mathrm{O}(100 \mu \mathrm{g} / \mathrm{mL})$. The estrogen compound $17 \beta$-estradiol (E2) and the antiestrogens 4hydroxytamoxifen (4-OH-TAM) and FUL (Sigma-Aldrich) were dissolved in dimethyl sulfoxide (DMSO) to $1 \mathrm{mM}$ stock concentration. The IGF-1R inhibitor BMS-536924 and dual $\mathrm{PI} 3 \mathrm{~K} / \mathrm{mammalian}$ target of rapamycin (mTOR) inhibitor BEZ235 (Selleck Chemicals LLC Houston, TX, USA) and the mitogen-activated protein kinase kinase (MEK) inhibitor U0126 (Promega, Madison, WI, USA), were prepared in DMSO at $10 \mathrm{mM}$ stock concentration.

\section{Cell culture, retrovirus production and establishment of IGF-1R stably overexpressing human breast cancer cell} line

MCF7 cells (American Type Culture Collection, Manassas, VA, USA) were cultured in RPMI 1640 medium (Gibco, Invitrogen, Carlsbad, CA, USA) supplemented with $10 \%$ fetal bovine serum (FBS) and $100 \mathrm{U} / \mathrm{mL}$ penicillin-streptomycin (Invitrogen). The retroviral vector pMSCV-neo-IGF-1R containing neomycin resistance gene and expressing human wild-type IGF-1R cDNA was provided by Dr. R. Baserga [24]. IGF-1R-encoding retroviruses were produced by transfection of pMSCVneo-IGF-1R into Phoenix Amphotropic packaging cells as previously described [25]. MCF7 cells were infected with freshly harvested retroviral supernatant. Two days later infected cells were selected by using $400 \mu \mathrm{g} / \mathrm{mL}$ 
neomycin. To establish individual positive clones from single cells, the neomycin selected cells were further subjected to limiting dilution in 96-well plates for twoweek colony selection. To rule out clonal artefacts, we picked up the wells containing three to five individual positive clones and collected and expanded the multiple clones to generate stable MCF7/IGF-1R cells.

\section{IGF-1 stimulative exposure}

Cells were placed in six-or twelve-well plates at $60 \%$ to $70 \%$ confluence in regular growth medium. The next day cells were starved overnight with $1 \%$ FBS medium. Following an additional two-hour serum deprivation with serum-free medium (SFM), cells were exposed to IGF-1 at a given dose and for a given time course, which was directly followed by cell lysis. To inhibit IGF-1-stimulated signaling, cells were pretreated with a kinase inhibitor in SFM for two hours prior to IGF-1 exposure.

\section{Cell drug treatments}

Cells were seeded with 10,000 cells/well in 96-well plates and incubated overnight. Prior to drug treatments, cells were starved for two days in phenol redfree RPMI 1640 medium (Gibco) supplemented with 5\% charcoal/dextran-stripped FBS (CDFBS) (HyClone Laboratories, Thermo Scientific, Logan, UT, USA) devoid of steroid hormones. Starved cells were then subjected to individual or combined drug treatments in triplicate and allowed to proliferate for four days.

\section{Sulforhodamine B colorimetric assay determining cell proliferation}

A sulforhodamine B (SRB) colorimetric assay [26,27] was used to determine cell proliferation that occurred in given drug treatments. In short, drug-treated cells in 96well plates were fixed with $30 \mu \mathrm{L}$ of $50 \%$ trichloroacetic acid directly added to $100 \mu \mathrm{L}$ of assay medium per well for 1 hour at $4^{\circ} \mathrm{C}$ on a shaker, gently washed five times with tap water and air-dried. Fixed cells were stained with $60 \mu \mathrm{L}$ of $0.4 \%$ SRB (dissolved in $1 \%$ acetic acid) at room temperature on a shaker for 30 minutes to allow the SRB to bind to protein, rinsed five times with $1 \%$ acetic acid to remove unbound dye and then air-dried. Subsequently, the protein-bound SRB in each well was solubilized with $200 \mu \mathrm{L}$ of $10 \mathrm{mM}$ Tris base solution $(\mathrm{pH}$ $>10$ ) for 10 minutes on a plate shaker and measured for its absorbance at $510 \mathrm{~nm}$ with a FLUOstar OPTIMA plate reader (BMG LABTECH, Offenburg, Germany). The SRB absorbance values at $510 \mathrm{~nm}$ are thus indicative of cell proliferation in response to drug treatments.

\section{D culture}

In addition to the SRB assay, a modified 3D culture was established to further examine cellular responses to growth factor IGF-1 stimulation and drug treatments. Briefly, a 96-well plate was coated with $30 \mu \mathrm{L} /$ well of 100\% Matrigel (354230, BD Matrigel ${ }^{\mathrm{TM}}$ Basement Membrane Matrix Growth Factor Reduced; BD Biosciences, Franklin Lakes, NJ, USA) at $37^{\circ} \mathrm{C}$ for 45 minutes. Single cells (10,000 cells/well) were suspended in $120 \mu \mathrm{L}$ of starving medium (phenol red-free RPMI 1640) containing 2\% soluble Matrigel and 5\% CDFBS (instead of complete medium) in which E2 was depleted, and the cells were then seeded on top of coating Matrigel. For given treatments, the concentrations of the drugs were adjusted for the total volume of $150 \mu \mathrm{L}$. Fresh medium was added every three or four days. After two weeks of culturing on Matrigel, the cells were fixed and stained with $3.7 \%$ formaldehyde in phosphate-buffered saline (PBS) containing $0.2 \%$ Triton $\mathrm{X}-100,0.25 \mu \mathrm{M}$ rhodamine phalloidin (Sigma) and $1 \mu \mathrm{g} / \mathrm{mL}$ Hoechst blue dye. Confocal imaging of $3 \mathrm{D}$ cell culture was performed with a Nikon ECLIPSE TE2000-E (Nikon Instruments, Tokyo, Japan).

\section{Cell lysis and Western blot analysis}

To prepare cell lysates for Western blot analysis, cells were washed three times with ice-cold PBS and lysed on ice for 30 minutes with lysis buffer $(50 \mathrm{mM}$ Tris, $\mathrm{pH}$ $7.5,150 \mathrm{mM} \mathrm{NaCl}, 2 \mathrm{mM}$ ethylenediaminetetraacetic acid, $0.1 \%$ sodium dodecyl sulfate (SDS), $1 \%$ Nonidet P40 and 1\% deoxycholic acid) freshly supplemented with 100-fold diluted protease inhibitor cocktail (P8340-ML; Sigma-Aldrich). Harvested lysate supernatant was measured for cellular protein concentration using the BCA $^{\text {TM }}$ Protein Assay Kit (Thermo Scientific, Rockford, IL, USA). A quantity of $30 \mu \mathrm{g} /$ lane total protein were separated by SDS-polyacrylamide gel electrophoresis on $7.5 \%$ acrylamide gel and electrophoretically transferred to polyvinylidene fluoride membrane (Millipore, Billerica, MA, USA). Prior to primary antibody probe, membrane was blocked for 1 hour at room temperature with $5 \%$ bovine serum albumin (BSA) in Tris-buffered saline Tween 20 (TBST) buffer (100 mM Tris, pH 7.4, 500 $\mathrm{mM} \mathrm{NaCl}, 0.05 \%$ Tween 20) or with I-Block buffer (Tropix, Applied Biosystems). Phospho-IGF-1R $\beta$ (Tyr1131) and phospho-ERK1/2 (Thr202/Tyr204) were probed in 5\% BSA-TBST buffer, whereas phospho-IGF$1 R \beta$ (Tyr1135/Tyr1136) and phospho-Akt (Ser473) were probed in I-Block buffer. HRP-or AP-conjugated secondary antibody incubation was performed in 5\% BSATBST or I-Block buffer, corresponding to the primary antibodies used. Protein bands were visualized by using the ECL Plus method (GE Healthcare, Little Chalfont, Buckinghamshire, UK), after which the membrane was scanned by using a Typhoon 9400 imager (GE Healthcare) or a Tropix Western-SuperStar ${ }^{\mathrm{TM}}$ procedure (Applied Biosystems) by placing the membrane in contact with standard X-ray film (GE Healthcare). 


\section{Immunofluorescence staining}

Cells seeded onto coverslips were washed once with PBS, fixed with $80 \%$ acetone in $\mathrm{H}_{2} \mathrm{O}$ and then blocked with $5 \%$ normal goat serum in PBS containing 0.05\% Tween 20. Expression of IGF-1R was detected by mouse monoclonal antibody against IGF-1R $\beta$ and labeled with Alexa Fluor 488 antimouse antibody. Nuclear DNA was stained with 4',6-diamidino-2-phenylindole. The stained cells were visualized under a fluorescence microscope (Nikon Eclipse E600; Nikon Instruments) at a $\times 60$ lens objective.

\section{Small interfering RNA transfection}

To silence target genes in cells, $50 \mathrm{nM}$ SMARTpool siRNA mix (Dharmacon Technologies, Thermo Scientific, Lafayette, CO, USA) was delivered into 15,000 cells/ well in 96-well plates by using a standard transfection method with DharmaFECT 4 transfection reagent (Dharmacon Technologies) according to the manufacturer's instructions. After 24 hours, the small interfering RNA (siRNA) transfection mixture was replaced with complete medium or with $5 \%$ CDFBS starving medium if drug treatment and SRB proliferation assay were included. Cells were kept in culture for one more day before analysis of knockdown or further treatment.

\section{Estrogen responsive element-luciferase reporter assay}

Cells were resuspended in antibiotic-free culture medium, and 40,000 cells/well were seeded into 48-well plates. By use of Lipofectamine PLUS reagent (Invitrogen), cells were transiently transfected with $0.16 \mu \mathrm{g}$ of the estrogen response element (ERE)-thymidine kinaseluciferase plasmid kindly provided by Dr. R. Michalides [28]. After three hours, cells were starved with 5\% CDFBS medium for two days. Following 12-hour treatments as indicated, cells were washed once with PBS and lysed with $1 \times$ passive lysis buffer (Dual-Luciferase Assay Kit; Promega). ERE-luciferase activity was measured using a luminometer (CentroXS ${ }^{3}$ LB 960; Berthold Technologies, Bad Wildbad, Germany).

\section{Statistical analysis}

Each average SRB absorbance value was derived from triplicate samples. Statistical analyses of all experimental data were performed using a two-sided Student's $t$-test. Significance was set at $P<0.05$.

\section{Results}

Ectopic IGF-1R expression in MCF7/IGF-1R cells enhances IGF-1R tyrosine kinase activity upon IGF-1 ligand stimulation

To establish a breast cancer cell line stably overexpressing IGF-1R, human MCF7 breast cancer cells were retrovirally transduced with a pMSCV-neo-IGF-1R vector and subjected to single-cloning selection following limiting dilution. The established MCF7/IGF-1R cell line stably expressed ectopic IGF-1R (Figure 1a), with expression approximately 10-fold that of parental MCF7 cells (Figure 1b). The proliferative response of MCF7/ IGF-1R cells to IGF-1 (half-maximal effective concentration $\left(\mathrm{EC}_{50}\right)=2.4 \mathrm{ng} / \mathrm{mL}$ ) was increased compared to MCF7 cells $\left(\mathrm{EC}_{50}=16.0 \mathrm{ng} / \mathrm{mL}\right)$ (Figure 1c).

IGF-1R contains a triple tyrosine cluster in the kinase domain, Tyr1131, Tyr1135 and Tyr1136, which is required for full kinase activation of IGF-1R [29]. To demonstrate IGF-1R autoactivation by ligand binding, time course (Figure $1 \mathrm{~b}$ ) and dose range exposures to IGF-1 (Figure 1d) were performed. Triple tyrosine IGF$1 \mathrm{R}$ phosphorylation was initiated rapidly and sustained for long time periods, reaching maximal levels at 100 ng/mL IGF-1. Overall, MCF7/IGF-1R cells displayed stronger IGF-1R autophosphorylation than parental MCF7 cells, indicating that MCF7/IGF-1R cells gained elevated intrinsic IGF-1R tyrosine kinase activity, which is necessary for the activation of the IGF-1-stimulated downstream signaling cascades.

IGF-1R signal transduction involves several major phosphorylation cascades, including the MAPK and PI3K pathways [30,31]. To confirm canonical IGF-1R signal transduction in the cell lines used, the activity of the downstream kinases ERK and Akt was determined. Concurrently with IGF-1R autophosphorylation, both ERK and Akt kinases became phosphorylated in parallel (Figure 1b). While maximal Akt phosphorylation was induced to a similar degree, maximal ERK phosphorylation was clearly higher in MCF7/IGF-1R cells than in MCF7 cells (Figures $1 \mathrm{~b}$ and $1 \mathrm{~d}$ ), appearing to be consistent with IGF-1R phosphorylation levels. These data indicate that the MAPK/ERK and PI3K/Akt signal transduction cascades are induced via ligand-activated IGF1R kinase activity, with increased MAPK/ERK signaling in the MCF7/IGF-1R cells.

Of note, equal levels of ER $\alpha$ were detected in both MCF7 and MCF7/IGF-1R cells (Figure 1b), indicating that overexpression and activation of IGF-1R does not influence $\mathrm{ER} \alpha$ expression in the MCF7/IGF-1R cell model.

High levels of IGF-1R signaling render MCF7/IGF-1R cells resistant to the antiestrogens tamoxifen and fulvestrant Next, we evaluated the sensitivity of MCF7/IGF-1R cells to $\mathrm{E} 2$ and the antiestrogens 4-OH-TAM and FUL. MCF7/IGF-1R cells were responsive to proliferative effects of $\mathrm{E} 2\left(\mathrm{EC}_{50}=5 \times 10^{-11} \mathrm{M}\right)$ (Additional file 1 ), similar to parental MCF7 cells. The proliferation induced by E2 $(1 \mathrm{nM})$ in both cell types was antagonized by 4-OH-TAM and FUL $\left(\mathrm{IC}_{50}=4 \times 10^{-8} \mathrm{M}\right)$ (Figure 2), indicating that ectopic IGF-1R expression in MCF7/IGF-1R cells does not affect ER $\alpha$ responses. 


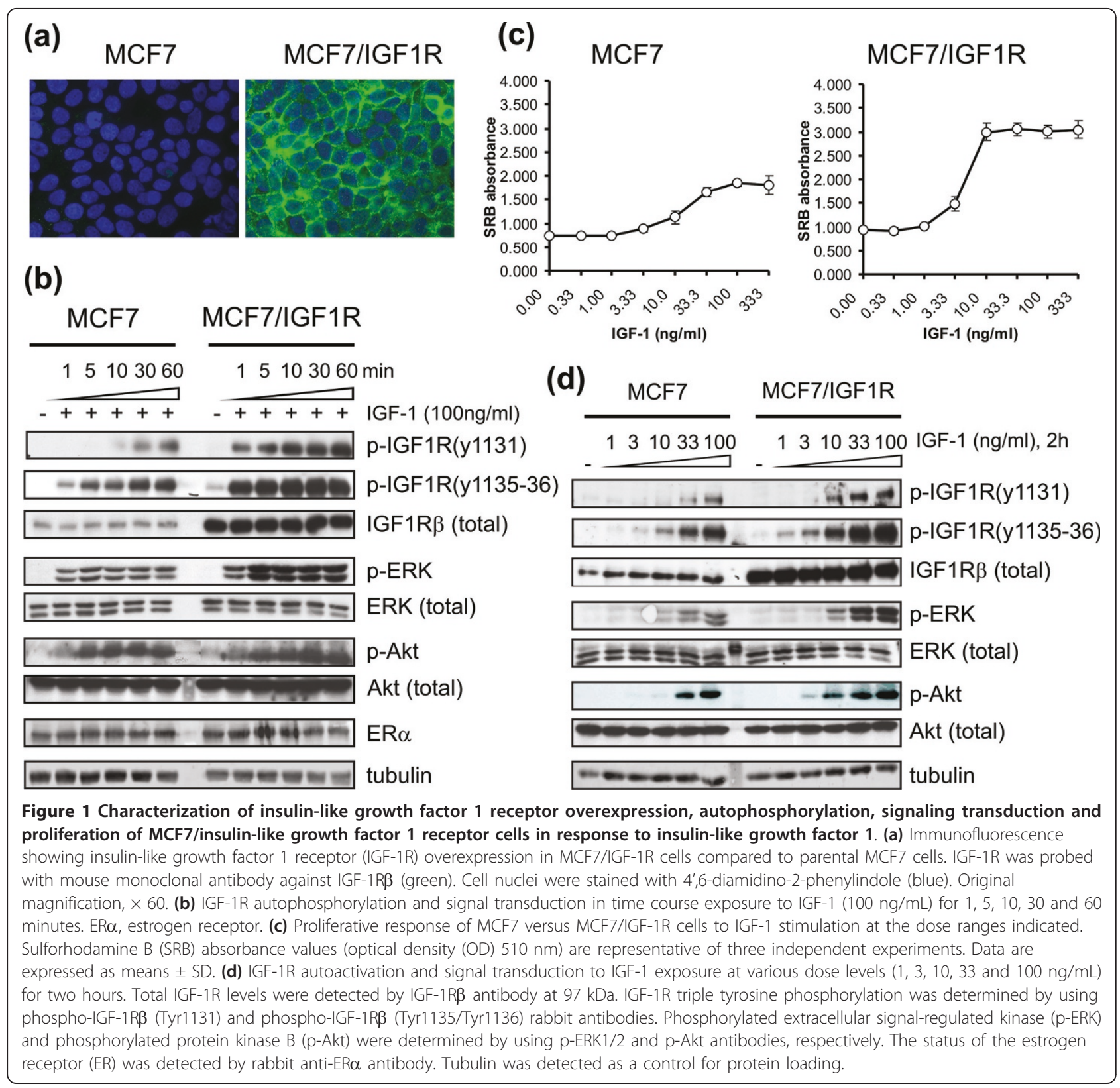

To address whether IGF-1 stimulation affects MCF7/ IGF-1R cellular sensitivity to antiestrogens, cells were treated with a concentration range of 4-OH-TAM (Figure $2 \mathrm{a}$ ) or FUL (Figure $2 \mathrm{~b}$ ) in combination with E2 (1 $\mathrm{nM})$, IGF-1 (100 $\mathrm{ng} / \mathrm{mL})$ or a combination of E2 and IGF-1 as indicated. While 4-OH-TAM and FUL at $10^{-6}$ $\mathrm{M}$ completely blocked E2-induced proliferation, IGF-1 stimulation desensitized MCF7/IGF-1R cells to the antiproliferative effects of 4-OH-TAM and FUL, sustaining proliferation level similar to that induced by IGF-1 alone and close to that induced by the IGF-1 and E2 co-treatment. IGF-1 stimulation also led to partial resistance of MCF7 cells to the antiestrogens at
$10^{-6} \mathrm{M}$, but it was much less significant than that of MCF7/IGF-1R cells. Together, these results indicate that enhanced IGF-1R signaling upon IGF-1 stimulation directly renders MCF7/IGF-1R cells insensitive to 4-OH-TAM and FUL, leading to strong antiestrogen resistance.

IGF-1R signaling induces antiestrogen resistance of MCF7/ IGF-1R cells in an ER-independent manner 4-OH-TAM and FUL regulate ER function differently. 4-OH-TAM is a competitive E2 antagonist and blocks ER transcriptional activity [32], whereas FUL antagonizes E2 and degrades ER protein [33]. This differential 


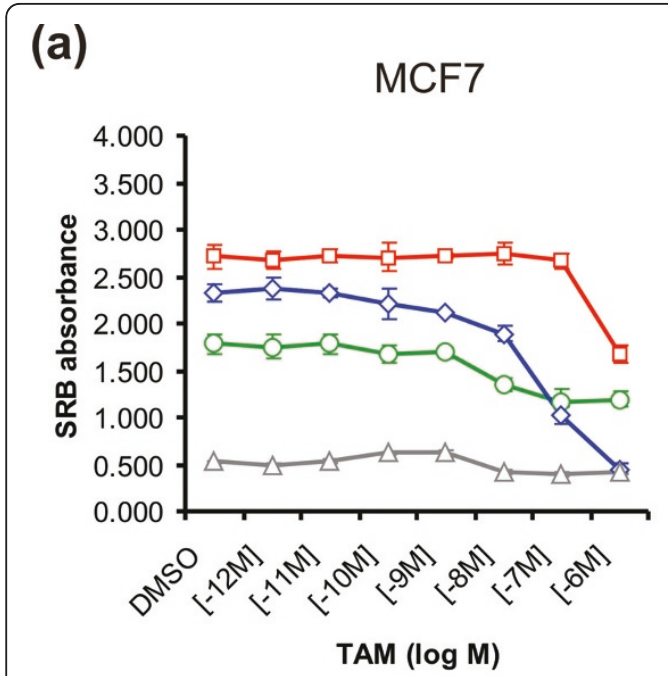

(b)

MCF7

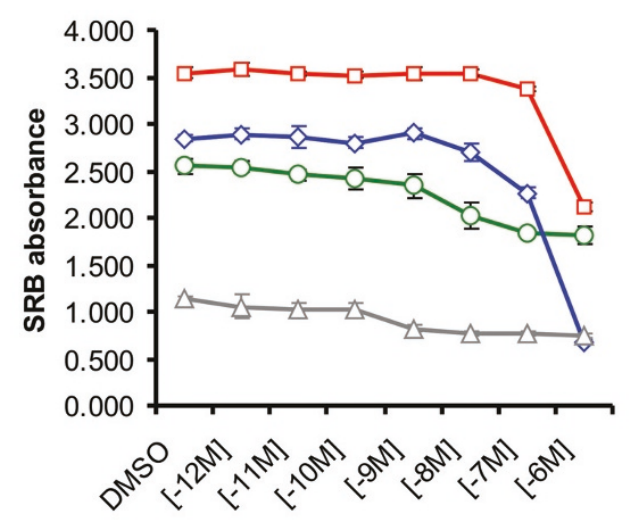

FUL $(\log M)$

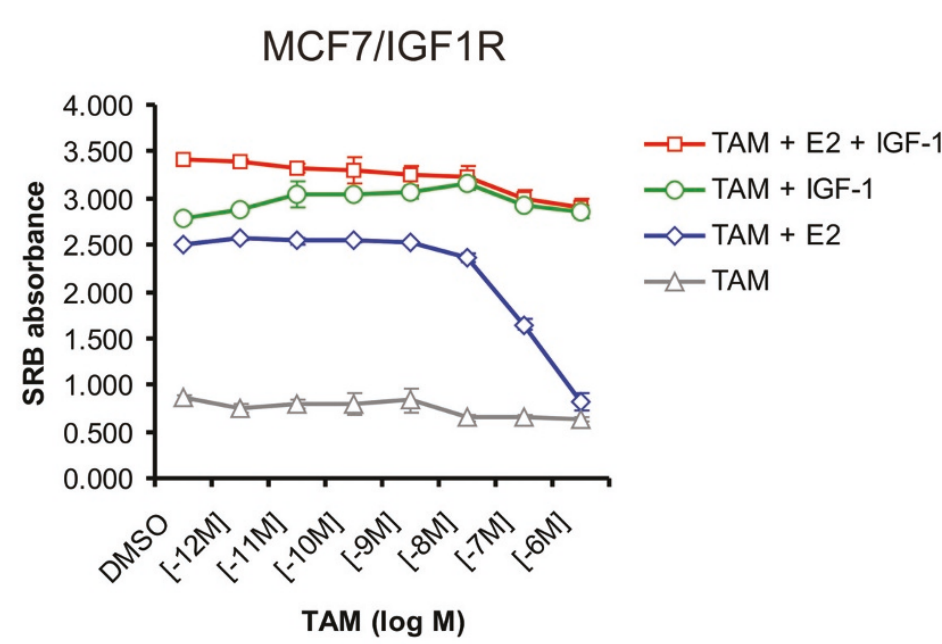

MCF7/IGF1R

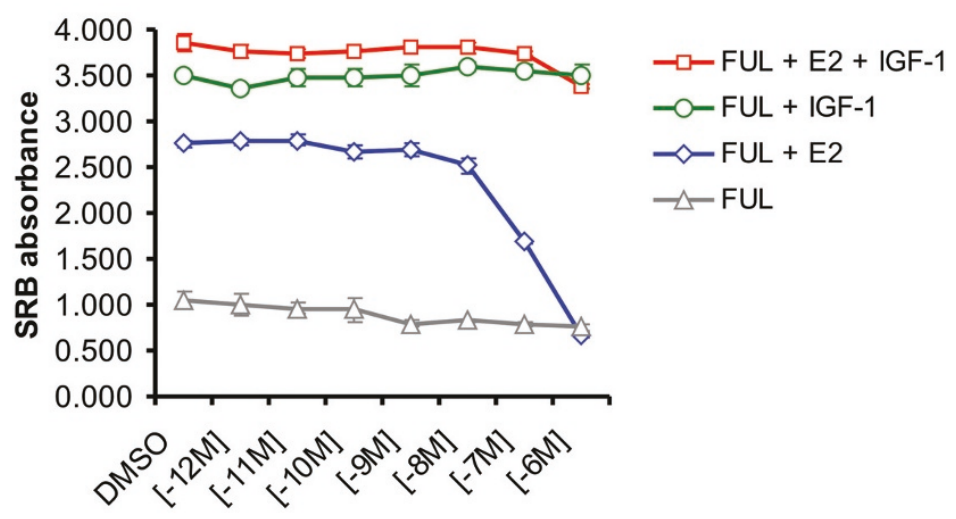

FUL $(\log M)$

Figure 2 Antiestrogen resistance of MCF7/IGF-1R cells is induced by high level of IGF-1R signaling. (a) Proliferative behavior of MCF7 versus MCF7/IGF-1R cells in response to 4-hydroxytamoxifen (TAM) in the dose range indicated in combination with estrogen 17ß-estradiol (E2) (1 nM), IGF-1 (100 ng/mL) or E2 (1 nM) plus IGF-1 (100 ng/mL). Dimethyl sulfoxide (DMSO) was used as a control. (b) Proliferative behavior of MCF7/IGF-1R versus MCF7 cells in response to fulvestrant (FUL) with the same dose range and treatments as were used for TAM. Each treatment was carried out in triplicate. SRB absorbance values are representative of three independent experiments. Data are expressed as means \pm SD.

ER regulation by $4-\mathrm{OH}-\mathrm{TAM}$ and FUL was equal in both MCF7 and MCF7/IGF-1R cells. 4-OH-TAM did not affect ER $\alpha$ expression, while FUL decreased ER $\alpha$ protein levels (Figure 3a).

To investigate whether tamoxifen resistance of MCF7/ IGF-1R cells is related to ER function, we silenced ER $\alpha$ by siRNA transfection, reaching $>80 \%$ knockdown of $\mathrm{ER} \alpha$ (Figure $3 \mathrm{~b}$ ). Compared to siRNA control (siCtrl), $\mathrm{ER} \alpha$ silencing $(\mathrm{siER} \alpha)$ significantly inhibited proliferation by E2 (65\% to $70 \% ; P<0.01$ ) (Figure 3c), but not by IGF-1 either alone or in cotreatment with E2 plus 4$\mathrm{OH}-\mathrm{TAM}(1 \mu \mathrm{M})$ (Figure $3 \mathrm{~d})$. In addition, the ERE-luciferase assay showed that IGF-1 did not affect EREmediated transcription (Figure 3e). While E2 led to a high level of ERE-mediated transcription, 4-OH-TAM sustained its antagonistic action on E2 and suppressed ER transcriptional ability in the presence of IGF-1 (Figure 3e). Furthermore, mRNA expression analysis demonstrated that IGF-1 stimulation did not significantly interfere with the expression of ER target genes, for instance, the known E2-responsive genes CXCL12 (chemokine (C-X-C motif) ligand 12; also named stromal cell-derived factor 1) and FOXC1 (forkhead box C1) [34,35]. The induction of both CXCL12 (Additional file 2a) and FOXC1 (Additional file 2b) gene expression in response to E2 was significantly inhibited by 4-OHTAM antagonistic activity in either the absence or the presence of IGF-1. 


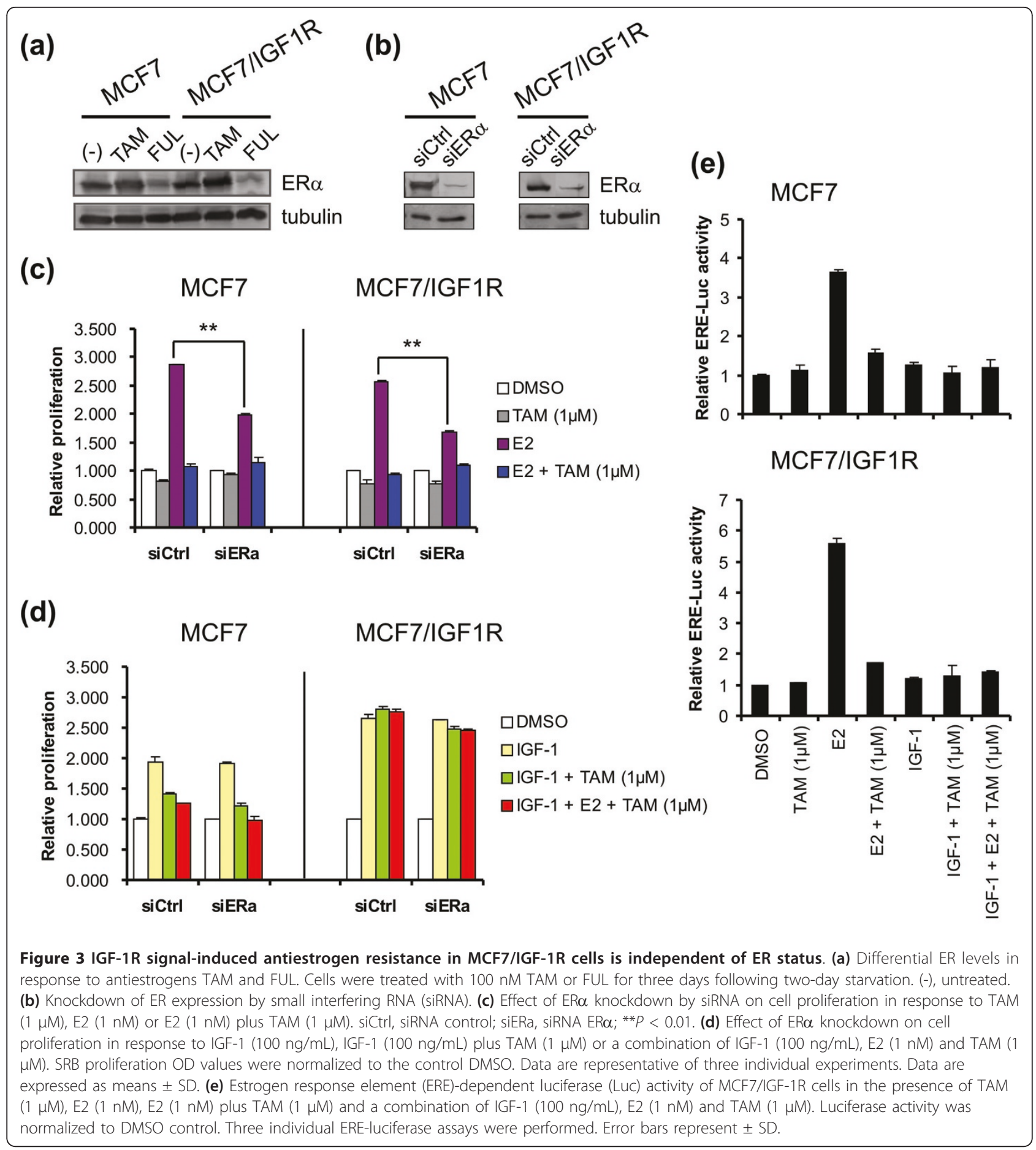

These results suggest that IGF-1R signal-mediated antiestrogen resistance in MCF7/IGF-1R cells does not involve ER $\alpha$-dependent processes. IGF-1-stimulated proliferation may run parallel to E2-induced proliferation and therefore is not inhibited by the antiestrogens 4$\mathrm{OH}-\mathrm{TAM}$ and FUL.
IGF-1R signaling involves the MAPK/ERK and PI3K/Akt pathways to mediate antiestrogen resistance of MCF7/ IGF-1R cells

Activation of IGF-1R signaling upon IGF-1 exposure led to downstream ERK and Akt phosphorylation (Figures $1 \mathrm{~b}$ and 1c). To evaluate the role of these kinase 
pathways in IGF-1R signal-induced antiestrogen resistance in MCF7/IGF-1R cells, we first used several specific kinase inhibitors, including the IGF-1R inhibitor BMS-536924 [36], the MEK inhibitor U0126 [37] and the PI3K inhibitor BEZ235 [38]. BMS-536924 efficiently blocked IGF-1R autophosphorylation by IGF-1 stimulation and downstream phosphorylation of both ERK and Akt by IGF-1R signal transduction (Figure 4a). U0126 $(10 \mu \mathrm{M})$ largely inhibited ERK phosphorylation without interfering with activation of either IGF-1R or Akt. BEZ235 $(1 \mu \mathrm{M})$ completely blocked Akt phosphorylation, leaving IGF-1R and ERK signaling intact (Figure 4a). These results suggest that, indeed, ERK and Akt are downstream from IGF-1R signaling in a linear fashion.
Next, the engagement of the ERK and Akt pathways in IGF-1R signal-mediated antiestrogen resistance in MCF7/IGF-1R cells was examined by use of the respective kinase inhibitors (Figures $4 \mathrm{~b}$ and $4 \mathrm{c}$ ). IGF-1 stimulation increased MCF7/IGF-1R proliferation by $60 \%$ to $64 \%(P<0.001)$ over the cotreatment of 4 -OH-TAM or FUL $(1 \mu \mathrm{M})$ with E2, whereas this IGF-1-promoted antiestrogen resistance was significantly abrogated by BMS536924, U0126 and BEZ235 equivalently to their inhibitory effects on relative kinase phosphorylation.

The key components involved in the PI3K/Akt and MAPK/ERK pathways have been well defined [39]. Using several other specific kinase inhibitors (Figure 5a) and targeting siRNA (Figure 5b and Additional file 3), we further (a)

\section{MCF7/IGF1R}

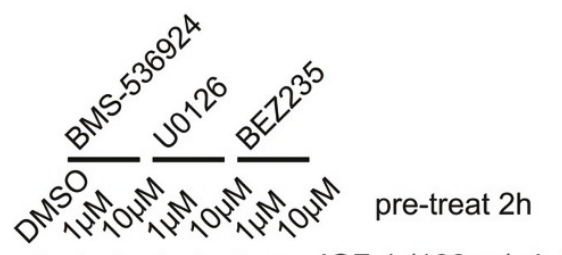

+++++++ IGF-1 (100ng/ml, 30min)

$=-\omega-\infty$ p-IGF1R(y1131)

- - e-IGF1R(y1135-36)

IGF1R $\beta$ (total)

$=\equiv \mathrm{p}-\mathrm{ERK}$

ERK (total)

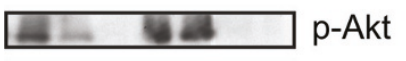

Akt (total)

$\Longrightarrow$ tubulin (b) MCF7/IGF1R

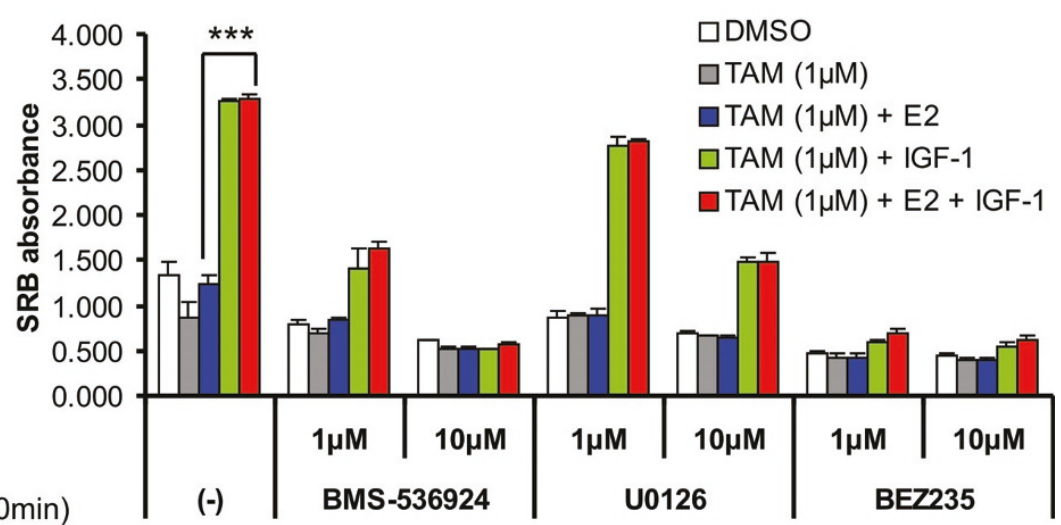

(c)

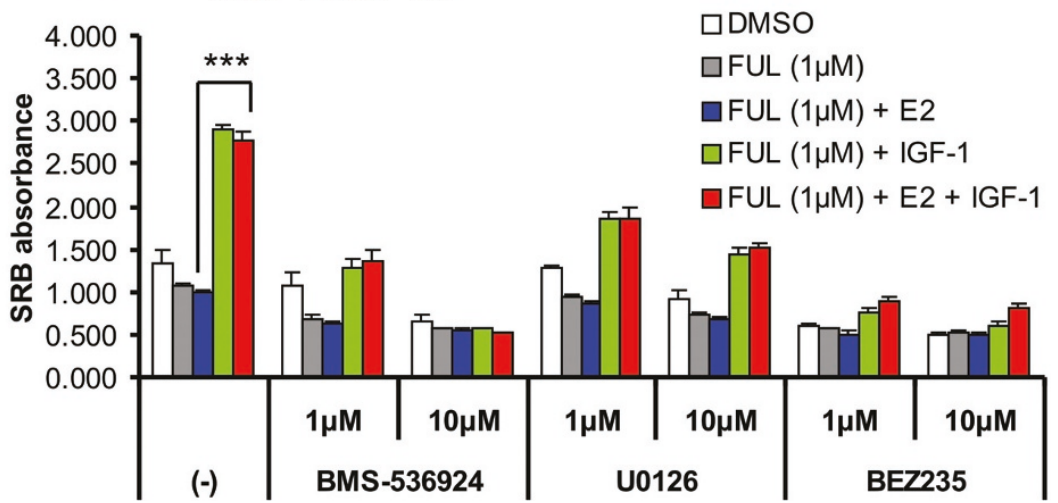

$(-)$

Figure 4 Involvement of mitogen-activated protein kinase/extracellular signal-regulated kinase and phosphatidylinositol 3-kinase/Akt in IGF-1R signal-mediated antiestrogen resistance of MCF7/IGF-1R cells. (a) Inhibitory effects of kinase inhibitors on IGF-1R autoactivation and its signaling transduction. (b) Inhibitory effects of kinase inhibitors on tamoxifen resistance of MCF7/IGF-1R cells in response to TAM (1 $\mu M$ ) individually or combined with E2 (1 nM) and IGF-1 (100 ng/mL) as indicated. (c) Inhibitory effects of kinase inhibitors on FUL resistance of MCF7/ IGF-1R cells in response to FUL $(1 \mu \mathrm{M})$ individually or combined with E2 $(1 \mathrm{nM})$ and IGF-1 $(100 \mathrm{ng} / \mathrm{mL})$ as indicated. (-), no kinase inhibitor. SRB absorbance values are representative of three independent experiments. Error bars represent \pm SD. ${ }^{* *} P<0.001$. 


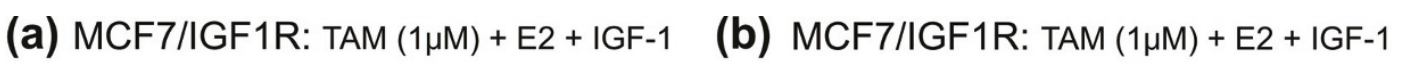
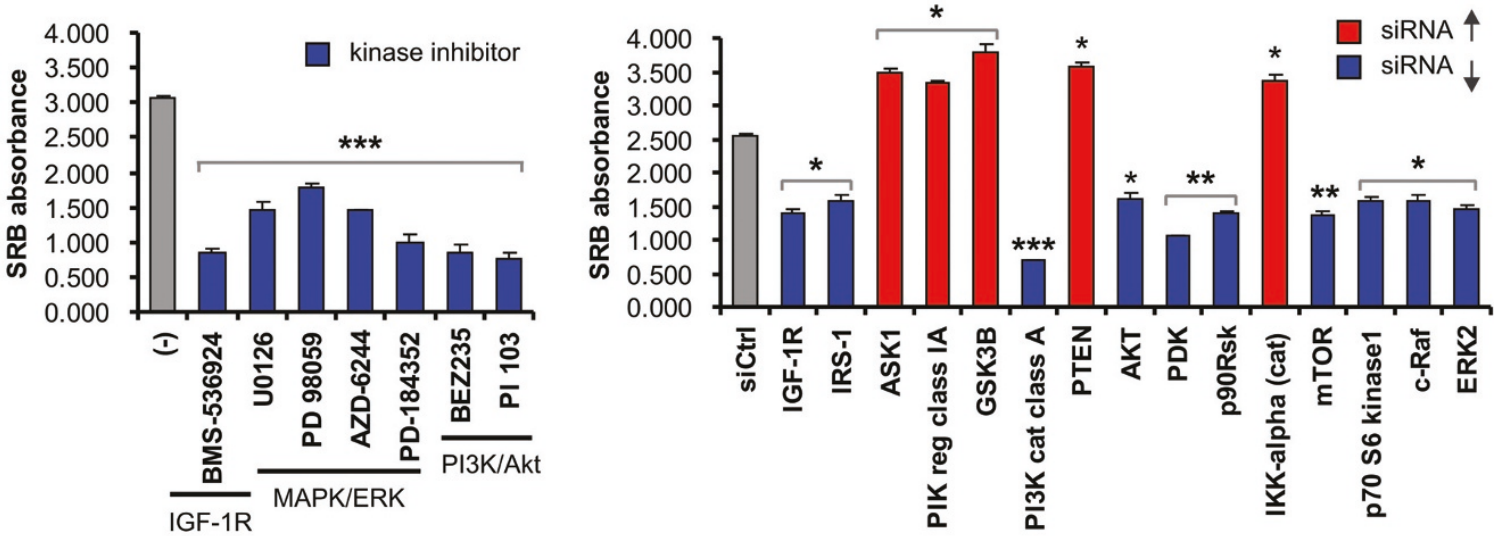

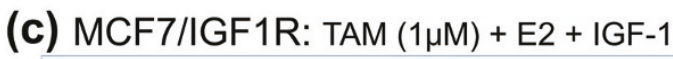

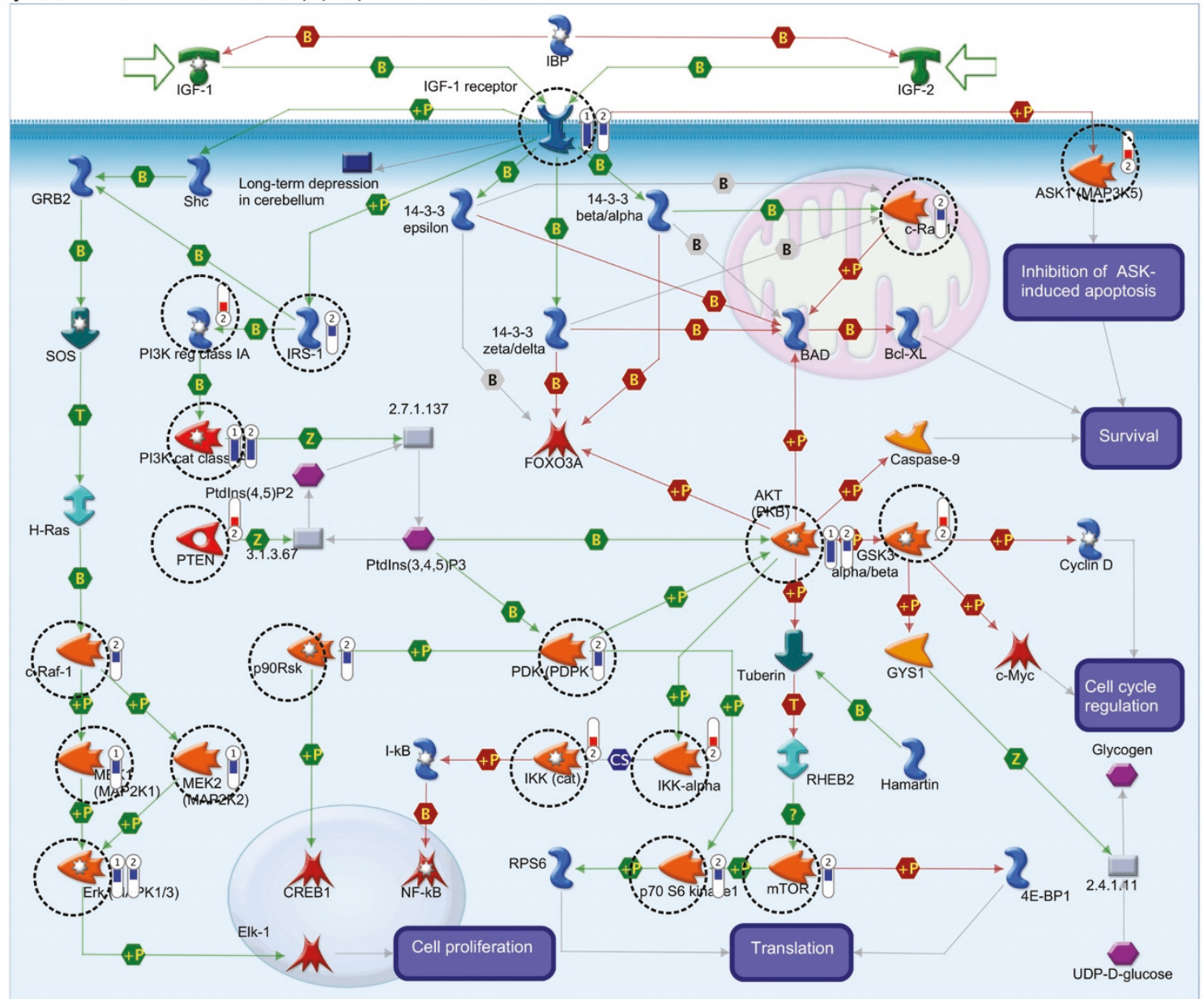

Figure 5 The key IGF-1R signaling components in the regulation of TAM resistance of MCF7/IGF-1R cells. (a) Selected kinase inhibitors inhibiting IGF-1R signal-mediated TAM resistance. (b) Selected siRNA targeting genes (as named) involved in IGF-1R signal-mediated TAM resistance. Concentrations used: TAM $(1 \mu \mathrm{M})$, E2 (1 nM) and IGF-1 (100 ng/mL). (-), no kinase inhibitor. siCtrl, nontargeting siRNA. Results are representative of duplicate experiments. Data are expressed as means $\pm \mathrm{SD}$. ${ }^{*} P<0.05$. ${ }^{* *} P<0.01$. ${ }^{* * *} P<0.001$. (c) MetaCore Pathway Analysis showing the functional activities of the key players (dashed circles) in IGF-1R signal-mediated TAM resistance. Fold changes in cell proliferation as the result of inhibition of selected kinase inhibitors or knockdown of target genes are given in Additional file 3. 1, experiment 1 (exp 1) with kinase inhibitors. 2, experiment 2 (exp 2) with siRNA. Red bar, increase in proliferation. Blue bar, decrease in proliferation. 
delineated the functional activities of the known PI3K/Akt and MAPK/ERK components in the 4-OH-TAM resistance of MCF7/IGF-1R cells and positioned them in the IGF-1R signaling map (Figure $5 \mathrm{c}$, dashed circles) by using MetaCore Pathway Analysis software (GeneGo, St. Joseph, MI, USA) according to fold changes in proliferation (Additional file 3 Table S1). As expected, inhibition of IGF-1R by either kinase inhibitor or siRNA silencing blocked IGF1 -stimulated proliferation (Figure 5c, exp 1 and 2, blue bars). Insulin receptor substrate 1 (IRS-1), which is known to be phosphorylated by autoactivated IGF-1R upon ligand binding, was shown to be involved in IGF-1R-mediated 4$\mathrm{OH}-\mathrm{TAM}$ resistance (Figure $5 \mathrm{c}$, exp 2, blue bar). Kinase inhibitors blocking the signaling of the MAPK/ERK and PI3K/Akt pathways led to overall inhibition of proliferation (Figure $5 c$, blue bars in exp 1). Silencing of the major MAPK/ERK and PI3K/Akt kinases c-Raf-1 (Raf1), ERK2 (MAPK1), PI3K cat class A (PIK3CA), Akt (AKT1), mTOR (FRAP1) and p70 S6 kinase 1 (RPS6KB1) largely abrogated IGF-1-induced 4-OH-TAM resistance (Figure 5c, exp 2, blue bars). The PI3K negative regulators PI3K reg class IA (PI3KR1) and phosphatase and tensin homolog (PTEN) greatly increased proliferation when knocked down (Figure $5 c$, exp 2, red bars), further indicating the role of the PI3K pathway in the 4-OH-TAM resistance of MCF7/IGF-1R cells. In a novel way, our results reveal that, when targeted by siRNA, phosphoinositide-dependent kinase (PDK)
(PDPK1) and p90Rsk (RPS6KA2), which are known positive regulators of transcription factor CREB1 (cyclic adenosine monophosphate-responsive element binding protein 1), decreased cell proliferation (Figure 5c, exp 2, blue bars), whereas inhibitor of nuclear factor $\kappa \mathrm{B}$ kinase subunit (IKK) (CHUK) and glycogen synthase kinase 3 (GSK3) (GSK3B), which are known inhibitors of transcription factors NF- $\kappa \mathrm{B}$ and $\mathrm{c}-\mathrm{Myc}$, significantly increased cell proliferation (Figure 5c, exp 2, red bars). In addition, silencing of apoptosis signal-regulating kinase 1 (ASK1) (MAP3K5), which is negatively regulated by IGF-1R phosphorylation to prevent apoptosis, enhanced cell proliferation (Figure 5c, exp 2, red bars).

Together, our results confirm that IGF-1R signaling incites multiple downstream cascades in which the key MAPK/ERK and PI3K/Akt components constitute the central signaling nodes that regulate IGF-1/IGF-1R signal-mediated proliferation and antiestrogen resistance in MCF7/IGF-1R cells.

\section{Tamoxifen resistance of IGF-1-stimulated MCF7/IGF-1R cells is induced in 3D culture}

Next, we further investigated the effect of IGF-1 stimulation on MCF7/IGF-1R 4-OH-TAM resistance in a more structurally and physiologically relevant context by use of a modified 3D culture. Both parental MCF7 (Figure 6a) and MCF7/IGF-1R cells (Figure 6b)
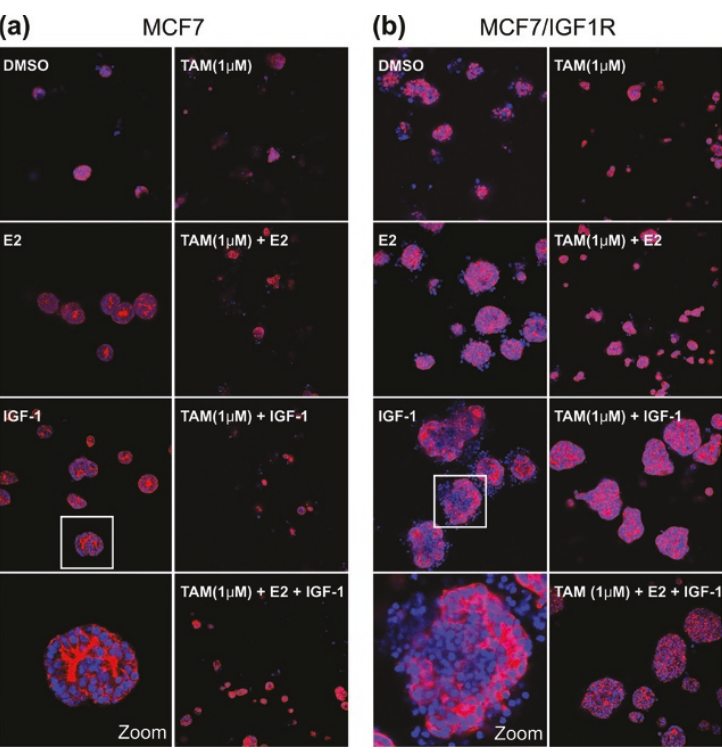

(c) MCF7IIGF1R

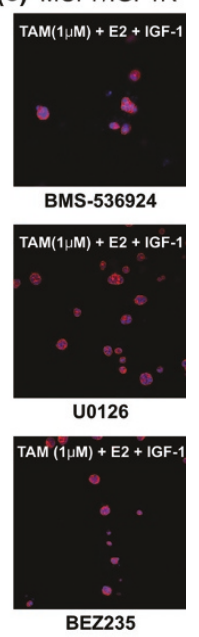

Figure 6 Three-dimensional responses of MCF7/IGF-1R cells to TAM $(1 \mu \mathrm{M})$, E2 and IGF-1. Compared to parental MCF7 cells (a), MCF7/IGF$1 R$ cells (b) in three-dimensional (3D) culture formed bigger acini in response to IGF-1 stimulation and displayed significant TAM resistance when treated with TAM $(1 \mu M)+E 2$ + IGF-1, which was removable by kinase inhibitors BMS-536924, U0126 and BEZ235 (c). Cells (10,000/well) were seeded in 96-well plates. Acini were formed on 100\% Matrigel and cultured for 14 days in starving medium containing 2\% Matrigel and 5\% charcoal/dextran-stripped fetal bovine serum with the treatments as indicated. Concentrations used: TAM (1 HM), E2 (1 nM) and IGF-1 (100 ng/ $\mathrm{mL}$ ). Confocal image original magnification, $\times 20$. Red, rhodamine phalloidin (actin). Blue, Hoechst blue stain. Results are representative of two individual experiments. 
were responsive to E2 or IGF-1 by forming acini on Matrigel, but the response was significantly larger in MCF7/IGF-1R cells with altered acinar morphogenesis (zoom images at bottom of Figures $6 \mathrm{a}$ and $6 \mathrm{~b}$ ). 4- $\mathrm{OH}-$ TAM effectively blocked E2-induced acini in both cell types (4-OH-TAM + E2). However, addition of IGF-1 (4-OH-TAM + E2 + IGF-1) overcame the antiproliferative effects of 4-OH-TAM and allowed acini growth of MCF7/IGF-1R cells but not MCF7 cells, demonstrating IGF-1-stimulated 4-OH-TAM resistance of MCF7/IGF-1R cells in 3D culture. Similarly to the SRB 2D assay, inhibition of IGF-1R/ERK/Akt signaling by respective kinase inhibitors restored 4$\mathrm{OH}-\mathrm{TAM}$ sensitivity of MCF7/IGF-1R cells in 3D culture (Figure 6c).

\section{At low concentrations, tamoxifen displays an agonistic behavior in IGF-1-stimulated MCF7/IGF-1R cells}

We have demonstrated that IGF-1 treatment of MCF7/ IGF-1R cells overruled the antiproliferative effect of tamoxifen (at $1 \mu \mathrm{M}$ ). However, we also note that at low concentrations of 4-OH-TAM, an increase in proliferation was triggered on top of IGF-1-driven proliferation (Figure 2a), suggesting a potential role for enhanced intrinsic IGF-1R signaling in tamoxifen resistance. To investigate to what extent IGF-1R signaling causes this 4-OH-TAM agonistic effect, cells were coexposed to 4$\mathrm{OH}-\mathrm{TAM}$ in doses of 10,33 or $100 \mathrm{ng} / \mathrm{mL}$ IGF-1, which were shown to cause different levels of sustained receptor and downstream signaling activation (Figure 1d). Consistently, IGF-1 promoted a 4-OH-TAM promitogenic effect in MCF7/IGF-1R cells but not in MCF7 cells, with the highest potential occurring at 4-OHTAM $10^{-9}$ to $10^{-8} \mathrm{M}$ (Figure 7a). This 4-OH-TAM promitogenic effect was most strongly induced by IGF-1 between 33 and $100 \mathrm{ng} / \mathrm{mL}$, concentrations which were shown to induce maximal IGF-1R signaling (Figure 1d).

As expected, at $10 \mathrm{nM}$ 4-OH-TAM, a marginal antagonistic effect was observed to block E2 (1 nM)-mediated proliferation (Figure $7 \mathrm{~b}$ ) and ERE-luciferase activity (Figure 7c) in both MCF7 and MCF7/IGF-1R cells. Interestingly, $10 \mathrm{nM}$ 4-OH-TAM provided a mild promitogenic effect, increasing IGF-1-dependent proliferation (17\% to 27\%; $P<0.05$ ) (Figure 7d) and ERE-mediated ER transcriptional activity in MCF7/IGF-1R cells $(P<0.05)$ (Figure 7e), whereas it remained inhibitory in parental MCF7 cells $(15 \%$ to $20 \% ; P<0.05)$ (Figures $7 d$ and $7 \mathrm{e}$ ). These agonistic effects were not observed for FUL.

To further evaluate whether ER $\alpha$ is functionally required for this 4-OH-TAM agonistic switch in MCF7/ IGF-1R cells, siRNA ER $\alpha$ knockdown experiments were performed. In siRNA control (siCrtrl) conditions, $10 \mathrm{nM}$ 4-OH-TAM maintained a promitogenic effect on IGF-1stimulated MCF7/IGF-1R cells ( $18 \%$ to $25 \% ; P<0.05)$, but ER $\alpha$ knockdown $(\operatorname{siER} \alpha)$ eliminated the proliferation increase induced by $10 \mathrm{nM}$ 4-OH-TAM (Figure 7f). These results imply that enhanced IGF-1R intrinsic kinase activity triggered this switch of 4-OH-TAM (10 $\mathrm{nM}$ ) from an ER $\alpha$ antiproliferative modulator into a promitogenic modulator, indicating an agonistic effect on ER.

\section{Tamoxifen agonistic behavior in MCF7/IGF-1R cells can be attributed to the MAPK/ERK pathway}

We also investigated whether the agonistic behavior of 4-OH-TAM (10 nM) in IGF-1-stimulated MCF7/IGF-1R cells is conferred via the ERK and Akt signaling pathways. Inhibition of IGF-1R signaling by BMS-536924 effected complete abrogation of IGF-1-stimulated proliferation and 4-OH-TAM (10 nM) agonistic action (Figure 8a). While $1 \mu M$ U0126 inhibited neither phosphorylation of ERK (Figure 4a) nor IGF-1-stimulated proliferation, it did clearly attenuate tamoxifen agonistic behavior $(P<0.01)$, with a subsequent competence in proliferative inhibition at $10 \mu \mathrm{M}$ (Figure 8a). IGF-1-stimulated proliferation was drastically restrained by BEZ235 at either 1 or $10 \mu \mathrm{M}$ (Figure $8 \mathrm{a}$ ). Similar inhibitory patterns by the kinase inhibitors were observed in parental MCF7 cells, except for the 4-OHTAM (10 nM) promitogenic effect (Additional file 4a).

We noted that although the BEZ235 inhibitory effect (even at $1 \mu \mathrm{M})$ was drastic, the 4-OH-TAM (10 nM) agonistic action seemed not to be completely abolished (Figure 8a). Therefore, further experiments with a lower dose range of BEZ235 were performed. While IGF-1R and ERK signaling remained unaffected in response to IGF-1, the phosphorylation level of Akt was diminished with an increase in the dose of BEZ235, largely at 0.1 $\mu \mathrm{M}$ and entirely at $0.5 \mu \mathrm{M}$ (Figure $8 \mathrm{~b}$ ). Likewise, the cell proliferation rate decreased correspondingly to Akt phosphorylation levels, significantly dropping at $0.1 \mu \mathrm{M}$ BEZ235 (Figure 8c), which occurred similarly in parental MCF7 cells (Additional file 4b). Intriguingly, the 4-OHTAM (10 nM) agonistic effect on MCF7/IGF-1R cells appeared irreversible by BEZ235 (Figure 8c). These data suggest that 4-OH-TAM (10 nM) agonist conversion results from elevated intrinsic IGF-1R/MAPK/ERK signaling in MCF7/IGF-1R cells.

\section{Discussion}

The underlying mechanisms for antiestrogen resistance are multifactorial and poorly understood. Studies of growth factor receptor-mediated resistance mechanisms have mainly focused on the RTK signaling by EGFR and HER2 $[1,5,7,22,40]$. Our data based on the MCF7/IGF$1 \mathrm{R}$ cell model demonstrate that, more than just a modulatory role, IGF-1R conveys its own ligand receptor signaling to drive resistance to tamoxifen and FUL. IGF-1R 


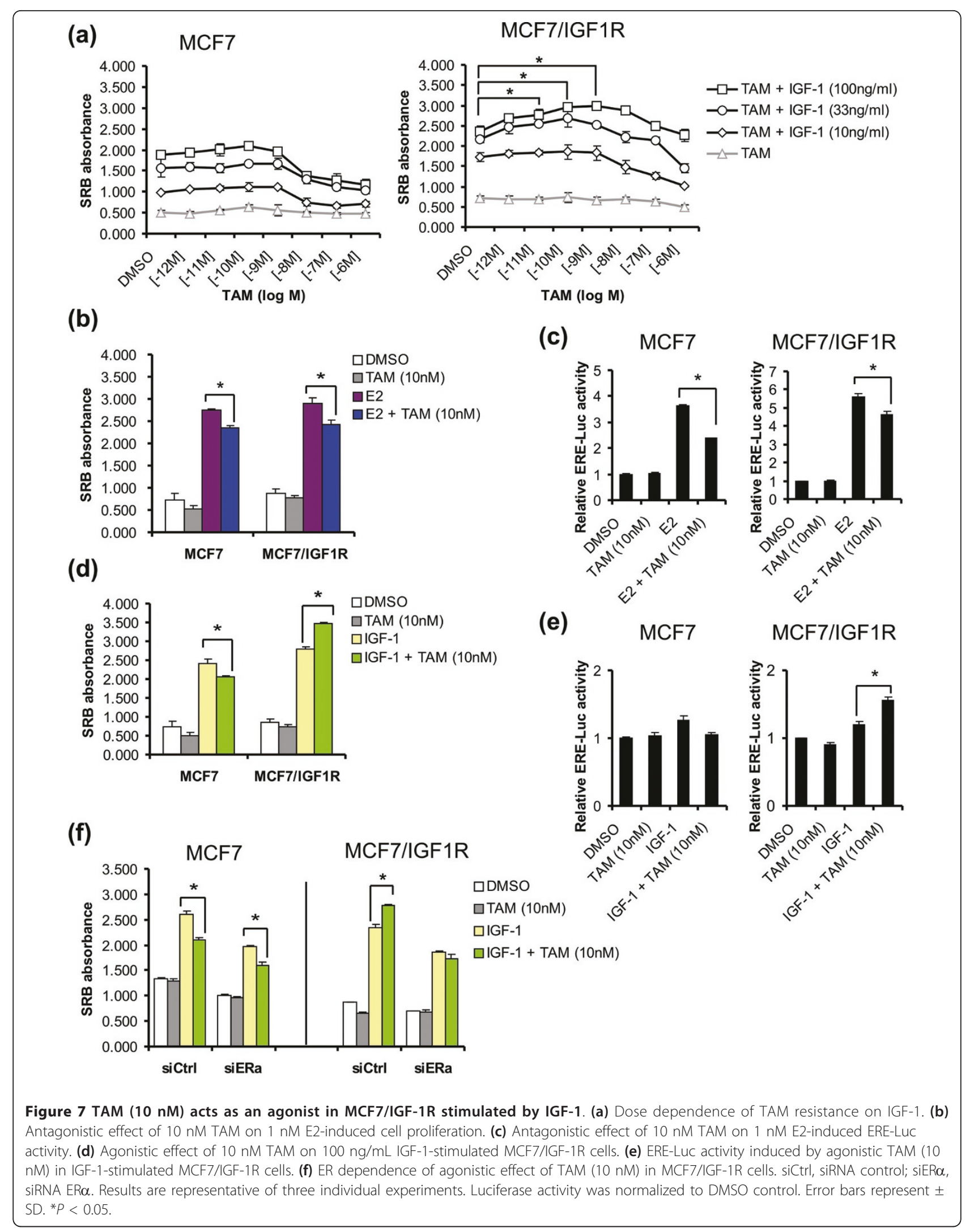




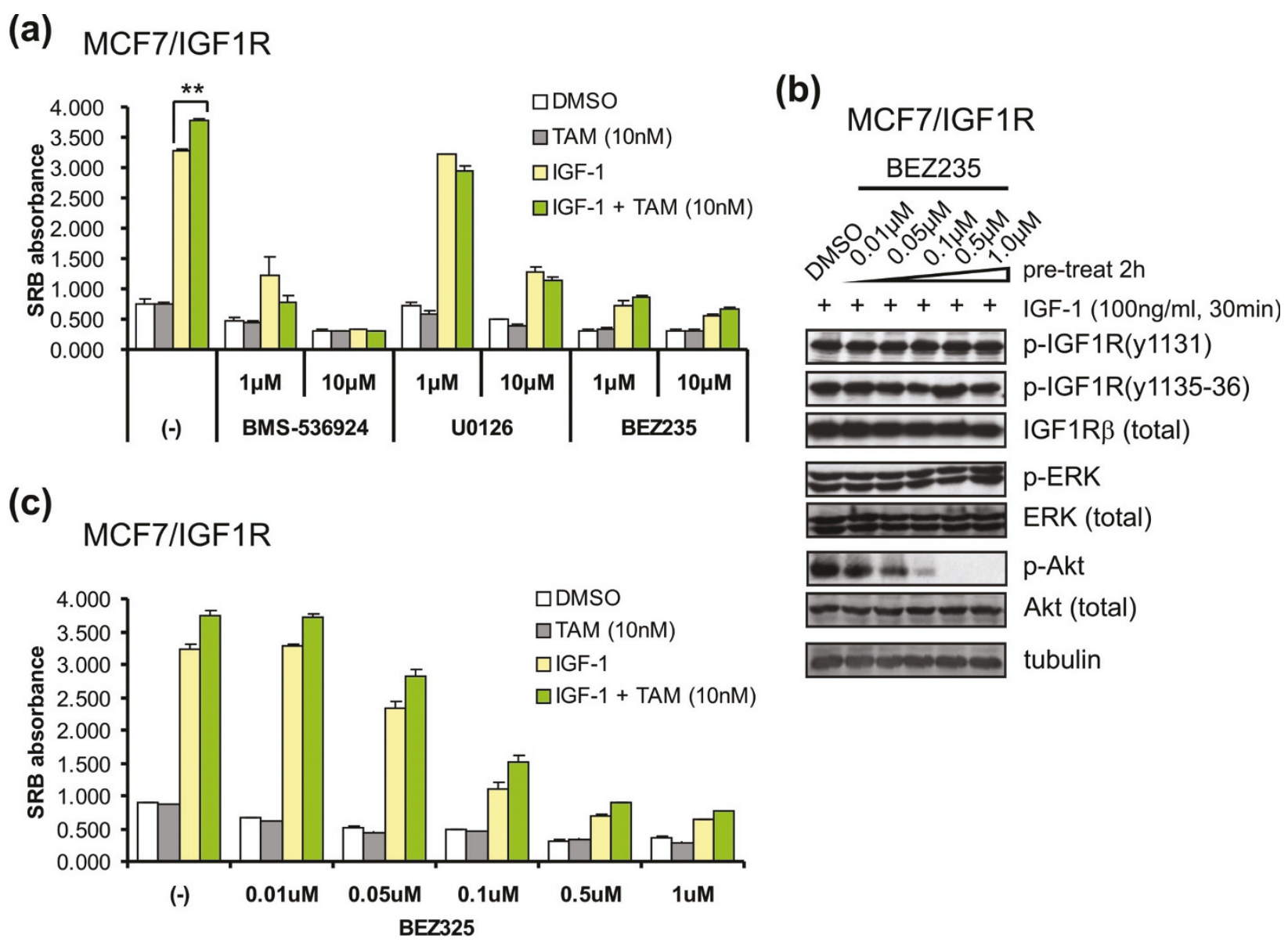

Figure 8 TAM (10 nM) agonistic behavior in MCF7/IGF-1R cells is not inhibited by phosphatidylinositol 3-kinase/Akt inhibitor BEZ235. (a) Inhibitory effects of kinase inhibitors BMS-536924, U0126 and BEZ235 on agonistic effect of TAM (10 nM) in the presence of IGF-1 (100 ng/ $\mathrm{mL}$ ). ${ }^{*} \mathrm{P}<0.01$. (b) Inhibitory effects of phosphatidylinositol 3-kinase (PI3K)/Akt inhibitor BEZ235 at various dose ranges on IGF-1R signaling. (c) Agonistic behavior of TAM (10 nM) in response to BEZ235 kinase inhibitor. (-), no BEZ235. Results are representative of three independent experiments. Data are expressed as means \pm SD.

has been shown to facilitate breast cancer survival, migration, invasion and metastasis [8-12]. Herein we have shown that there is a causative mechanism of the IGF-1/IGF-1R axis in the antiestrogen drug resistance of breast cancer cells. IGF-1R signal-mediated tamoxifen resistance in 3D culture indicates the likelihood that these findings can be extended to the in vivo situation.

Clinical studies have revealed that phosphorylation of IGF-1R is correlated with poor outcomes of breast cancers, whereas total IGF-1R level is not [15]. Our data show that enhanced RTK activity of IGF-1R is required for the antiestrogen-resistant phenotype of MCF7/IGF$1 \mathrm{R}$ cells and that IGF-1R does not elicit antiresistance in the presence of the IGF-1R inhibitor BMS-536924. We propose that elevated IGF-1R signaling can be an important element of breast cancer antiestrogen resistance.

Resistance to antiestrogens may occur de novo in initial endocrine therapy or may be acquired later, after an early response. Antiestrogen-resistant breast cancer cells increase their utilization of nongenomic signaling pathways, while genomic ER action seems less active, since in most cases there is no loss of ER when resistance to endocrine therapy develops [18,40-42]. Several successive studies have shown that changes in ER levels do not underlie antiestrogen resistance of breast cancers [43-46]. Other studies have reported that overexpression of IGF-1R or its major substrate, IRS-1, in ER-positive breast cancer cells augments cell proliferation and reduces estrogen growth dependence [47-49]. In addition, phosphorylation of IGF-1R in human breast cancers has no correlation with ER expression [15]. In support of these findings, we have shown that overexpression and phosphorylation of IGF-1R in antiestrogenresistant MCF7/IGF-1R cells affected neither ER protein levels nor their transcriptional activity in response to estrogen and antiestrogens. In E2-depleted starving 
medium, exposure of MCF7/IGF-1R cells to IGF-1 (100 $\mathrm{ng} / \mathrm{mL}$ ) abolished the E2 requirement for cell growth and resulted in resistance to antiestrogens $(1 \mu \mathrm{M})$. Importantly, ER $\alpha$ knockdown by siRNA did not alleviate IGF$1 \mathrm{R}$ signal-mediated tamoxifen resistance in MCF7/IGF$1 R$ cells, and ER $\alpha$ degradation by FUL did not rescue the resistant phenotype either. Furthermore, ERE reporter assay and mRNA expression analysis demonstrated that E2-induced ER transcriptional activity and expression of the ER target genes CXCL12 and FOXC1 are inhibited by 4-OH-TAM in the presence or absence of IGF-1. Thus, our data indicate that the IGF-1/IGF-1R signaling route can incite antiestrogen resistance of MCF7/IGF-1R cells, without cross-talk with the ER $\alpha$ pathway at the moment of IGF-1 ligand stimulation. Therefore, we emphasize that IGF-1R signaling may act as a crucial contributor to antiestrogen resistance in breast cancer, independently of E2 and regardless of ER status.

We have determined that upon IGF-1 ligand stimulation, IGF-1R conveys its signal via the MAPK/ERK and PI3K/Akt pathways, the major downstream pathways integrating signals from RTKs, to mediate antiestrogen resistance in MCF7/IGF-1R cells. Blockage of either pathway by various kinase inhibitors restores cell sensitivity to the antiestrogens tamoxifen and FUL. Specific siRNA silencing of IGF-1R's substrate, IRS-1, and the key MAPK/ERK and PI3K/Akt kinase components confirms their individual roles in the IGF-1R signalmediated 4-OH-TAM resistance of MCF7/IGF-1R cells and implies roles for the oncogene PIK3CA, the tumor suppressor PTEN, the apoptotic modulator ASK1 (MAP3K5) and transcription factor regulators such as PDK (PDPK), p90Rsk (RPS6KA2), IKK (CHUK) and GSK3 $(G S K 3 B)$. These results suggest that targeting either IGF-1R itself or downstream MAPK/ERK and PI3K/Akt signaling components may resensitize breast cancer cells to antiestrogen tamoxifen and FUL.

Tamoxifen can have both agonist and antagonist properties $[18,50,51]$. Herein we have shown that 4-OHTAM switches from an antagonist to an agonist in IGF1-stimulated MCF7/IGF-1R cells. Interestingly, this effect was primarily observed at a low concentration of 4-OH-TAM (10 nM) and was associated with mild EREmediated ER transcriptional activity. Knockdown of ER $\alpha$ abrogated this agonistic effect of 4-OH-TAM. In addition, this agonistic 4-OH-TAM (10 nM)-promoted proliferation appeared to be dependent on increased MAPK/ERK signaling. Phosphorylation levels of ERKs were increased in IGF-1-stimulated MCF7/IGF-1R cells, significantly higher than those in parental MCF7 cells, whereas Akt phosphorylation remained similar. These results are congruent with those of an earlier study which presented the same activation patterns of ERK and Akt downstream of IGF-1/IGF-1R signaling [49].
Other studies have shown that in acquired tamoxifenresistant cells or MCF7/HER2 cells, enhanced EGFR and HER2 expression increases MAPK/ERK signaling, leading to agonist activity of tamoxifen, but Akt remains at equal levels $[18,42,52-54]$. Particularly in tamoxifenresistant cells, tamoxifen at $100 \mathrm{nM}$ acts as an agonist by increasing proliferation and even triggers ERK phosphorylation as quickly as E2 does [55]. Our data indicate that the tamoxifen agonistic properties can be induced by enhanced activation of IGF-1R signaling and suggest that an increase in MAPK/ERK cascades downstream of IGF-1R RTK signaling may be essential for tamoxifen agonism at low concentrations.

\section{Conclusions}

Our findings using the MCF7/IGF-1R breast cancer cell line model provide evidence that elevated IGF-1R signaling determines the sensitivity of breast cancer cells to antiestrogens and further define the role of the IGF-1/ IGF-1R axis in the pleiotropic mechanisms of breast cancer antiestrogen resistance. The MCF7/IGF-1R cell line represents a useful model for investigating the critical elements in IGF-1/IGF-1R-driven proliferation and antiestrogen resistance.

\section{Additional material}

Additional file 1: Figure S1. Responsiveness of MCF7 versus MCF7/ insulin-like growth factor 1 receptor (IGF-1R) cells to $17 \beta$-estradiol (E2). The sulforhodamine B (SRB) data shown are representative of three individual experiments. Data are expressed as means \pm SD.

Additional file 2: Figure S2. Expression levels of E2-responsive genes CXCL12 and FOXC1 in the presence of tamoxifen, E2 and IGF1. For microarray analysis of gene expression, MCF7/IGF-1R cells were seeded at $60 \%$ confluence in 6 -cm plates and subjected to three-day starvation in $5 \%$ charcoal/dextran-stripped fetal bovine serum medium prior to treatments with 4-hydroxytamoxifen (TAM) $(10 \mu \mathrm{M})$, E2 (10 nM) and IGF-1 (100 ng/mL) as indicated. Each treatment was performed in triplicate. After 6 hours of treatment, cells were harvested and total RNA was extracted using an RNA isolation kit (Ambion, Inc., Austin, TX, USA). RNA quality and integrity were assessed by using the Agilent 2100 Bioanalyzer System (Agilent Technologies, Santa Clara, CA, USA). The Affymetrix 3' IVT Express Kit (Affymetrix, Santa Clara, CA, USA) was used to synthesize biotin-labeled CRNA, and this was hybridized to an Affymetrix HG-U133 PM Array plate reader. Raw expression data were obtained by probe summarization and background correction according to the robust multiarray averaging method [56]. Median normalization of raw expression data and identification of differentially expressed genes using a random variance $t$-test was performed using BRB-ArrayTools [57] version 4.1.0 Beta 2 Release (developed by Dr. Richard Simon and BRBArrayTools Development Team members). Expression levels of the E2responsive genes CXCL12 and FOXC1 were normalized to their levels in control and dimethyl sulfoxide-treated cells. Data are expressed as means \pm SD.

Additional file 3: Table S1. Effects of various kinase inhibitors and siRNA on IGF/E2/TAM-induced cell proliferation of MCF7/IGF-1R cells.

Additional file 4: Figure S3. (a) Inhibitory effects of kinase inhibitors BMS-536924, U0126 and BEZ235 on MCF7 cells in response to TAM (10 $\mathrm{nM})$ and IGF-1 (100 ng/mL) as indicated. (b) Inhibitory effects of kinase inhibitor BEZ35 at a dose range on cell proliferation of MCF7 cells in response to TAM (10 nM) and IGF-1 (100 ng/mL) as indicated. Original 
data are representative of three independent experiments. Data are expressed as means \pm SD

\section{Abbreviations}

Akt: protein kinase B; AP: alkaline phosphatase; ASK1: apoptosis signalregulating kinase 1; $\mathrm{BCl}-2$ : B-cell lymphoma 2; $\mathrm{BCl}-\mathrm{xL}$ : B-cell lymphoma extra large; BSA: bovine serum albumin; CDFBS: charcoal/dextran-stripped fetal bovine serum; $C X C L 12$ : chemokine (C-X-C motif) ligand 12 chemokine ligand 12 (stromal cell-derived factor 1); DAPI: 4',6-diamidino-2-phenylindole; DMSO: dimethyl sulfoxide; E2: estrogen 17ß-estradiol; $\mathrm{EC}_{50}$ : half-maximal effective concentration; EGFR: epidermal growth factor receptor; ER: estrogen receptor; ERE: estrogen response element; ERK: extracellular signal-regulated kinase; FBS: fetal bovine serum; FOXC1: forkhead box C1; FUL: fulvestrant; GSK3: glycogen synthase kinase 3; HER2: human epidermal growth factor receptor 2; HRP: horseradish peroxidase; $\mathrm{IC}_{50}$ : half-maximal inhibitory concentration; IGF-1: insulin-like growth factor 1; IGF-1R: insulin-like growth factor 1 receptor; IKK: inhibitor of nuclear factor KB kinase subunit; IRS-1: insulin receptor substrate 1; MAPK: mitogen-activated protein kinase; MEK: mitogen-activated protein kinase kinase; mTOR: mammalian target of rapamycin; Myc: myelocytomatosis viral oncogene homolog; NF-kB: nuclear factor KB; 4-OH-TAM: 4-hydroxytamoxifen; PBS: phosphate-buffered saline; PDK: phosphoinositide-dependent kinase; PI3K: phosphatidylinositol 3-kinase; PTEN: phosphatase and tensin homolog; RTK: receptor tyrosine kinase; SFM: serum-free medium; siRNA: small interfering RNA; SRB: sulforhodamine B.

\section{Acknowledgements}

This study was performed within the framework of the research project Nuclear Receptors in Targeted Cancer Therapy (T3-107), which is funded by Top Institute Pharma (TI Pharma), Leiden, The Netherlands.

\section{Authors' contributions}

$Y Z, J M$ and BvdW designed the research and wrote the manuscript. $Y Z$ and MM performed the majority of the experiments. YZ, SR and LP established and modified the 3D Matrigel assay. $\mathrm{HdB}$ helped with 3D confocal imaging. All authors read and approved the final manuscript.

\section{Competing interests}

The authors declare that they have no competing interests.

Received: 23 November 2010 Revised: 3 April 2011

Accepted: 19 May 2011 Published: 19 May 2011

\section{References}

1. Musgrove EA, Sutherland RL: Biological determinants of endocrine resistance in breast cancer. Nat Rev Cancer 2009, 9:631-643.

2. Zilli M, Grassadonia A, Tinari N, Di Giacobbe A, Gildetti S, Giampietro J, Natoli C, lacobelli S: Molecular mechanisms of endocrine resistance and their implication in the therapy of breast cancer. Biochim Biophys Acta 2009, 1795:62-81.

3. Tonini G, Schiavon G, Fratto ME, Vincenzi B, Santini D: Hormono-biological therapy in metastatic breast cancer: preclinical evidence, clinical studies and future directions. Expert Opin Biol Ther 2008, 8:221-234.

4. Riggins RB, Schrecengost RS, Guerrero MS, Bouton AH: Pathways to tamoxifen resistance. Cancer Lett 2007, 256:1-24.

5. Frogne T, Benjaminsen RV, Sonne-Hansen K, Sorensen BS, Nexo E, Laenkholm AV, Rasmussen LM, Riese DJ, de Cremoux P, Stenvang J, Lykkesfeldt AE: Activation of ErbB3, EGFR and Erk is essential for growth of human breast cancer cell lines with acquired resistance to fulvestrant. Breast Cancer Res Treat 2009, 114:263-275.

6. Arpino G, Wiechmann L, Osborne CK, Schiff R: Crosstalk between the estrogen receptor and the HER tyrosine kinase receptor family: molecular mechanism and clinical implications for endocrine therapy resistance. Endocr Rev 2008, 29:217-233.

7. Dawood S, Cristofanilli M: Endocrine resistance in breast cancer: what really matters? Ann Oncol 2007, 18:1289-1291.

8. Werner H, Bruchim I: The insulin-like growth factor-I receptor as an oncogene. Arch Physiol Biochem 2009, 115:58-71.
9. Surmacz E: Function of the IGF-I receptor in breast cancer. J Mammary Gland Biol Neoplasia 2000, 5:95-105.

10. Sachdev D, Zhang X, Matise I, Gaillard-Kelly M, Yee D: The type I insulinlike growth factor receptor regulates cancer metastasis independently of primary tumor growth by promoting invasion and survival. Oncogene 2010, 29:251-262.

11. Klinakis A, Szabolcs M, Chen G, Xuan S, Hibshoosh H, Efstratiadis A: Igf1r as a therapeutic target in a mouse model of basal-like breast cancer. Proc Natl Acad Sci USA 2009, 106:2359-2364.

12. Sachdev D, Hartell JS, Lee AV, Zhang X, Yee D: A dominant negative type I insulin-like growth factor receptor inhibits metastasis of human cancer cells. J Biol Chem 2004, 279:5017-5024.

13. Taunk NK, Goyal S, Moran MS, Yang Q, Parikh R, Haffty BG: Prognostic significance of IGF-1R expression in patients treated with breastconserving surgery and radiation therapy. Radiother Oncol 2010, 96:204-208.

14. Ouban A, Muraca P, Yeatman T, Coppola D: Expression and distribution of insulin-like growth factor-1 receptor in human carcinomas. Hum Pathol 2003, 34:803-808.

15. Law JH, Habibi G, Hu K, Masoudi H, Wang MY, Stratford AL, Park E, Gee JM, Finlay P, Jones HE, Nicholson Rl, Carboni J, Gottardis M, Pollak M, Dunn SE: Phosphorylated insulin-like growth factor-1/insulin receptor is present in all breast cancer subtypes and is related to poor survival. Cancer Res 2008, 68:10238-10246.

16. Fagan DH, Yee D: Crosstalk between IGF1R and estrogen receptor signaling in breast cancer. J Mammary Gland Biol Neoplasia 2008, 13:423-429.

17. Sisci D, Surmacz E: Crosstalk between IGF signaling and steroid hormone receptors in breast cancer. Curr Pharm Des 2007, 13:705-717.

18. Massarweh S, Osborne CK, Creighton CJ, Qin L, Tsimelzon A, Huang S, Weiss H, Rimawi M, Schiff R: Tamoxifen resistance in breast tumors is driven by growth factor receptor signaling with repression of classic estrogen receptor genomic function. Cancer Res 2008, 68:826-833.

19. Knowlden JM, Hutcheson IR, Barrow D, Gee JM, Nicholson RI: Insulin-like growth factor-I receptor signaling in tamoxifen-resistant breast cancer: a supporting role to the epidermal growth factor receptor. Endocrinology 2005, 146:4609-4618

20. Parisot JP, Hu XF, DeLuise M, Zalcberg JR: Altered expression of the IGF-1 receptor in a tamoxifen-resistant human breast cancer cell line. $\mathrm{Br} J$ Cancer 1999, 79:693-700

21. Song RX, Chen Y, Zhang Z, Bao Y, Yue W, Wang JP, Fan P, Santen RJ: Estrogen utilization of IGF-1-R and EGF-R to signal in breast cancer cells. J Steroid Biochem Mol Biol 2010, 118:219-230.

22. Santen RJ, Fan P, Zhang Z, Bao Y, Song RX, Yue W: Estrogen signals via an extra-nuclear pathway involving IGF-1R and EGFR in tamoxifen-sensitive and -resistant breast cancer cells. Steroids 2009, 74:586-594.

23. Huang X, Gao L, Wang S, McManaman JL, Thor AD, Yang X, Esteva FJ, Liu B: Heterotrimerization of the growth factor receptors erbB2, erbB3, and insulin-like growth factor-I receptor in breast cancer cells resistant to herceptin. Cancer Res 2010, 70:1204-1214.

24. Romano G, Prisco M, Zanocco-Marani T, Peruzzi F, Valentinis B, Baserga R: Dissociation between resistance to apoptosis and the transformed phenotype in IGF-I receptor signaling. J Cell Biochem 1999, 72:294-310.

25. Swift S, Lorens J, Achacoso P, Nolan GP: Rapid production of retroviruses for efficient gene delivery to mammalian cells using 293T cell-based systems. Curr Protoc Immunol 2001, Chapter 10:Unit 10.17C.

26. Vichai V, Kirtikara K: Sulforhodamine B colorimetric assay for cytotoxicity screening. Nat Protoc 2006, 1:1112-1116.

27. Skehan P, Storeng R, Scudiero D, Monks A, McMahon J, Vistica D, Warren JT, Bokesch H, Kenney S, Boyd MR: New colorimetric cytotoxicity assay for anticancer-drug screening. J Natl Cancer Inst 1990, 82:1107-1112.

28. Michalides R, Griekspoor A, Balkenende A, Verwoerd D, Janssen L, Jalink K, Floore A, Velds A, van't Veer L, Neefjes J: Tamoxifen resistance by a conformational arrest of the estrogen receptor a after PKA activation in breast cancer. Cancer Cell 2004, 5:597-605.

29. Lopaczynski W, Terry C, Nissley P: Autophosphorylation of the insulin-like growth factor I receptor cytoplasmic domain. Biochem Biophys Res Commun 2000, 279:955-960.

30. Shelton JG, Steelman LS, White ER, McCubrey JA: Synergy between PI3K/ Akt and Raf/MEK/ERK pathways in IGF-1R mediated cell cycle 
progression and prevention of apoptosis in hematopoietic cells. Cell Cycle 2004, 3:372-379.

31. Vincent AM, Feldman EL: Control of cell survival by IGF signaling pathways. Growth Horm IGF Res 2002, 12:193-197.

32. Sutherland RL, Green MD, Hall RE, Reddel RR, Taylor IW: Tamoxifen induces accumulation of MCF 7 human mammary carcinoma cells in the $G_{0} / G_{1}$ phase of the cell cycle. Eur J Cancer Clin Oncol 1983, 19:615-621.

33. Nicholson Rl, Gee JMW, Francis AB, Manning DL, Wakeling AE, Katzenellenbogen $\mathrm{BS}$ : Observations arising from the use of pure antiestrogens on estrogen-responsive (Mcf-7) and estrogen growthindependent (K3) human breast-cancer cells. Endocr Relat Cancer 1995, 2:115-121.

34. Fan M, Yan PS, Hartman-Frey C, Chen L, Paik H, Oyer SL, Salisbury JD, Cheng AS, Li L, Abbosh PH, Huang TH, Nephew KP: Diverse gene expression and DNA methylation profiles correlate with differential adaptation of breast cancer cells to the antiestrogens tamoxifen and fulvestrant. Cancer Res 2006, 66:11954-11966.

35. Hall JM, Korach KS: Stromal cell-derived factor 1, a novel target of estrogen receptor action, mediates the mitogenic effects of estradiol in ovarian and breast cancer cells. Mol Endocrinol 2003, 17:792-803.

36. Litzenburger BC, Kim HJ, Kuiatse I, Carboni JM, Attar RM, Gottardis MM, Fairchild CR, Lee AV: BMS-536924 reverses IGF-IR-induced transformation of mammary epithelial cells and causes growth inhibition and polarization of MCF7 cells. Clin Cancer Res 2009, 15:226-237.

37. Duncia JV, Santella JB 3rd, Higley CA, Pitts WJ, Wityak J, Frietze WE, Rankin FW, Sun JH, Earl RA, Tabaka AC, Teleha CA, Blom KF, Favata MF, Manos EJ, Daulerio AJ, Stradley DA, Horiuchi K, Copeland RA, Scherle PA, Trzaskos JM, Magolda RL, Trainor GL, Wexler RR, Hobbs FW, Olson RE: MEK inhibitors: the chemistry and biological activity of U0126, its analogs, and cyclization products. Bioorg Med Chem Lett 1998, 8:2839-2844.

38. Serra V, Markman B, Scaltriti M, Eichhorn PJ, Valero V, Guzman M, Botero ML, Llonch E, Atzori F, Di Cosimo S, Maira M, Garcia-Echeverria C, Parra JL, Arribas J, Baselga J: NVP-BEZ235, a dual PI3K/mTOR inhibitor, prevents PI3K signaling and inhibits the growth of cancer cells with activating PI3K mutations. Cancer Res 2008, 68:8022-8030.

39. Chitnis MM, Yuen JS, Protheroe AS, Pollak M, Macaulay VM: The type 1 insulin-like growth factor receptor pathway. Clin Cancer Res 2008, 14:6364-6370

40. Arpino G, De Angelis C, Giuliano M, Giordano A, Falato C, De Laurentiis M, De Placido S: Molecular mechanism and clinical implications of endocrine therapy resistance in breast cancer. Oncology 2009, 77(Suppl 1):23-37.

41. Yue W, Fan P, Wang J, Li Y, Santen RJ: Mechanisms of acquired resistance to endocrine therapy in hormone-dependent breast cancer cells. J Steroid Biochem Mol Biol 2007, 106:102-110.

42. Shou J, Massarweh S, Osborne CK, Wakeling AE, Ali S, Weiss H, Schiff R: Mechanisms of tamoxifen resistance: increased estrogen receptor-HER2/ neu cross-talk in ER/HER2-positive breast cancer. J Natl Cancer Inst 2004, 96:926-935.

43. Hurtado A, Holmes KA, Geistlinger TR, Hutcheson IR, Nicholson RI, Brown M, Jiang J, Howat WJ, Ali S, Carroll JS: Regulation of ERBB2 by oestrogen receptor-PAX2 determines response to tamoxifen. Nature 2008, 456:663-666.

44. Green KA, Carroll JS: Oestrogen-receptor-mediated transcription and the influence of co-factors and chromatin state. Nat Rev Cancer 2007, 7:713-722.

45. Varma H, Conrad SE: Antiestrogen ICI 182,780 decreases proliferation of insulin-like growth factor I (IGF-I)-treated MCF-7 cells without inhibiting IGF-I signaling. Cancer Res 2002, 62:3985-3991.

46. Johnston SR, Saccani-Jotti G, Smith IE, Salter J, Newby J, Coppen M, Ebbs SR, Dowsett M: Changes in estrogen receptor, progesterone receptor, and pS2 expression in tamoxifen-resistant human breast cancer. Cancer Res 1995, 55:3331-3338.

47. Surmacz E, Burgaud JL: Overexpression of insulin receptor substrate 1 (IRS-1) in the human breast cancer cell line MCF-7 induces loss of estrogen requirements for growth and transformation. Clin Cancer Res 1995, 1:1429-1436.

48. Guvakova MA, Surmacz E: Overexpressed IGF-I receptors reduce estrogen growth requirements, enhance survival, and promote E-cadherinmediated cell-cell adhesion in human breast cancer cells. Exp Cell Res 1997, 231:149-162.
49. Bartucci M, Morelli C, Mauro L, Ando S, Surmacz E: Differential insulin-like growth factor I receptor signaling and function in estrogen receptor (ER)-positive MCF-7 and ER-negative MDA-MB-231 breast cancer cells. Cancer Res 2001, 61:6747-6754.

50. Osborne CK: Tamoxifen in the treatment of breast cancer. N Engl J Med 1998, 339:1609-1618.

51. Hodges LC, Cook JD, Lobenhofer EK, Li L, Bennett L, Bushel PR, Aldaz CM, Afshari $C A$, Walker $C L$ : Tamoxifen functions as a molecular agonist inducing cell cycle-associated genes in breast cancer cells. Mol Cancer Res 2003, 1:300-311.

52. Ghayad SE, Vendrell JA, Larbi SB, Dumontet C, Bieche I, Cohen PA: Endocrine resistance associated with activated ErbB system in breast cancer cells is reversed by inhibiting MAPK or PI3K/Akt signaling pathways. Int J Cancer 2010, 126:545-562.

53. Bender LM, Nahta R: Her2 cross talk and therapeutic resistance in breast cancer. Front Biosci 2008, 13:3906-3912.

54. Berstein LM: Molecular mechanisms of mutual effects of the pathological processes during combination of diabetes mellitus and cancer. Biochemistry (Mosc) 2003, 68:703-706.

55. Ignatov A, Ignatov T, Roessner A, Costa SD, Kalinski T: Role of GPR30 in the mechanisms of tamoxifen resistance in breast cancer MCF-7 cells. Breast Cancer Res Treat 2010, 123:87-96.

56. Irizarry RA, Hobbs B, Collin F, Beazer-Barclay YD, Antonellis K, Scherf U, Speed TP: Exploration, normalization, and summaries of high density oligonucleotide array probe level data. Biostatistics 2003, 4:249-264.

57. Wright GW, Simon RM: A random variance model for detection of differential gene expression in small microarray experiments. Bioinformatics 2003, 19:2448-2455.

doi:10.1186/bcr2883

Cite this article as: Zhang et al: Elevated insulin-like growth factor 1 receptor signaling induces antiestrogen resistance through the MAPK/ ERK and PI3K/Akt signaling routes. Breast Cancer Research 2011 13:R52.

\section{Submit your next manuscript to BioMed Central and take full advantage of:}

- Convenient online submission

- Thorough peer review

- No space constraints or color figure charges

- Immediate publication on acceptance

- Inclusion in PubMed, CAS, Scopus and Google Scholar

- Research which is freely available for redistribution

Submit your manuscript at www.biomedcentral.com/submit
Ciomed Central 